\title{
REKONSTRUKSI PROBLEMATIKA SOSIAL DALAM UPAYA PEMBERDAYAAN DAN PERLINDUNGAN ANAK TERLANTAR MELALUI ADOPSI
}

\author{
Ms.Udin \\ Fakultas Dakwah Dan Ilmu Komunikasi \\ Universitas Islam Negeri Mataram
}

\begin{abstract}
One of the problems in this country is the large number of school-aged children who cannot continue schooling due to disasters and others, in large cities abandoned children with school age can easily be found alongside roads, terminals, stations and so on. Children, whatever their background is an investment in the future, every child in essence has the rights and obligations as a child in a family, but in reality there is often a neglect of the fulfillment of children's rights, this is probably due to economic conditions, family social and psychology. Child protection is a business that establishes conditions in which every child can exercise his rights and obligations. The protection of children is a manifestation of the existence of justice in a society. Thus, child protection must be sought in various fields of state and community life. Child protection is a field of national development. Protecting children is protecting people is building whole people
\end{abstract}

Key Word : Problematika Sosial, Perlindungan Anak, Adopsi 


\section{A. Pendahuluan}

Gempa beruntun yang melanda Lombok selama tiga pekan terakhir mengakibatkan jatuhnya korban jiwa, kerusakan infrastruktur, dan puluhan ribu warga mengungsi. Data Penanganan Darurat Bencana gempa Lombok mencatat gempa bumi mengakibatkan 564 korban meninggal dunia dan 390.529 jiwa penduduk mengungsi. Kabupaten Lombok Utara merupakan lokasi terdampak paling parah akibat gempa bumi. Kepala Pusat Data, Informasi, dan Humas Badan Nasional Penanggulangan Bencana (BNPB) Sutopo Purwo Nugroho merinci jumlah korban meninggal dunia paling banyak berada di Kabupaten Lombok Utara, yaitu 467 orang. Jumlah korban jiwa meninggal dunia sebanyak 564 orang dengan rincian, yaitu Kabupaten Lombok Utara sebanyak 467 orang, Kabupaten Lombok Barat sebanyak 44 orang, dan Kabupaten Lombok Timur sebanyak 31 orang. ${ }^{1}$

Trauma masyarakat Lombok belum lagi usai akibat gempa bumi bermagnitudo 7, Minggu 5 Agustus 2018. Gempa kembali mengguncang Lombok dengan magnitudo 6,2, Kamis pada pukul 12.25 WIB. Sontak masyarakat kembali panik. Jumlah korban pun diprediksi bakal terus bertambah mengingat tim masih terus mencari korban diantara reruntuhan bangunan. Tidak sedikit bangunan dan infrastruktur yang rusak termasuk akses ke beberapa lokasi gempa masih tertutup.

Bencana gempa di Lombok Tidak saja menyebabkan timbulnya korban jiwa ataupun menimbulkan kerusakan rumah dan infrastruktur, tetapi juga meninggalkan trauma yang luar biasa, terutama bagi anak- anak. Kejadian luar biasa yang dialami seseorang dan tidak mampu diantisipasinya seperti bencana alam dapat menyebabkan terganggunya kejiwaan orang tersebut. Keadaan ini semakin diperparah dengan jumlah pengungsi yang tidak sesuai

1 https://nasional.kompas.com/read/2018/10/01/21091241/hampir-2-bulanberlalu-ini-update-korban-gempa-lombok-dari-bnpb, tanggal 30 November 2018 
dengan tempat pengungsian. Mereka kebanyakan tidak mendapatkan tempat yang layak untuk tinggal bahkan hanya untuk beristirahat saja. Kurangnya pasokan makanan yang bergizi juga menyebabkan para pengungsi mudah terserang penyakit. Mereka tidak mampu bersekolah dan harus tidur di tempat yang seadanya. Bencana alam dipastikan akan berdampak pada psikologis anak-anak. Kondisi ini dapat menyebabkan terjadinya penurunan kualitas mental sebagai dampak traumatis kejadian tersebut.

Salah satu yang menjadi permasalahan di negeri ini adalah banyaknya anak usia sekolah yang tidak dapat melanjutkan sekolah akibat bencana dan lain lain, dikota-kota besar anak-anak terlantar dengan usia sekolah dapat dengan mudah ditemui dipinggir jalan, terminal, stasiun dan sebagainya. Anak-anak apapun latar belakangnya merupakan investasi masa depan, setiap anak pada hakikatnya mempunyai hak dan kewajiban sebagai seorang anak dalam sebuah keluarga, akan tetapi dalam kenyataannya seringkali dijumpai adanya pengabaian terhadap pemenuhan hak-hak anak, hal ini tidak tertutup kemungkinan dikarenakan kondisi ekonomi, sosial dan psikologi keluarganya. ${ }^{2}$

Perlindungan dan pemenuhan kebutuhan orang tua untuk anak dapat terwujud, apabila orang tua merasa mampu untuk mencukupi hak-hak anak, sehingga anak tidak menjadi terlantar. Tetapi pada kenyataannya, anak-anak dilahirkan tanpa adanya pemenuhan hak yang seimbang. Dengan adanya hal tersebut, orang tua akan menyerahkan anak yang dilahirkan ke panti asuhan, dengan harapan hak-hak anak akan dapat dipenuhi. Dalam hal inilah, Negara melakukan perlindungan kepada anak-anak terlantar yang berada di panti asuhan, melalui Dinas Kesejahteraan Sosial yang ada.

Perlindungan anak adalah suatu usaha yang mengadakan kondisi dimana setiap anak dapat melaksanakan hak dan kewajibanya. Adapun perlindungan anak merupakan perwujudan adanya keadilan

2 . Bastian Tafal, Pengangkatan Anak Menurut Hukum Adat Serta Akibat-Akibat Hukumnya Di Kemudian Hari, (Jakarta : Rajawali Press, 2005), hlm 35 
dalam suatu masyarakat. Dengan demikian maka perlindungan anak harus diusahakan dalam berbagai bidang kehidupan bernegara dan bermasyarakat. Perlindungan anak merupakan suatu bidang pembangunan nasional. Melindungi anak adalah melindungi manusia adalah membangun manusia seutuhnya. Hakekat pembangunan nasional adalah upaya yang dilaksanakan oleh semua komponen bangsa dalam rangka mencapai tujuan bersama (Pasal 1 Undang-Undang No. 25 tahun 2004), mengabaikan masalah perlindungan anak tidak akan memantabkan Pembangunan Nasional. Akibat tidak adanya perlindungan anak akan menimbulkan berbagai permasalahan sosial yang dapat mengganggu ketertiban, keamanan, dan pembangunan nasional. Maka ini berarti bahwa perlindungan anak harus diusahakan apabila kita ingin mengusahakan pembangunan nasional yang memuaskan.

Nasib bangsa ini pada beberapa dekade ke depan akan ditalangi oleh anak-anak masa ini, hanya saja dalam kenyataannya di Indonesia masalah-masalah seputar kehidupan anak masih banyak djumpai; pertama dari segi pendidikan, banyak anak terancam tak bisa melanjutkan sekolah setiap tahunnya, kenyataan yang begitu ironis juga terlihat dari berubahnya prioritas keluarga untuk lebih mendahulukan kelangsungan hidup dibanding menyekolahkan anakanak. Kedua, dari terbatasnya pelayanan kesehatan, masalah gizi, perlakuan kasar, eksploitasi seksual komersial hingga perdagangan anak dan sebagainya. Dilihat dari kesemua masalah tersebut tak dapat disangkal berawal dari masalah ekonomi.

Menurut Vivit Muntarbhorn, ada beberapa kelompok anak yang berada dalam kondisi yang tidak menguntungkan dalam kondisi ekonomi, sosial dan psikologi yakni sebagai berikut :

1. Anak-anak pedesaan,

2. Anak-anak jalanan dan daerah kumuh perkotaan,

3. Anak perempuan, 


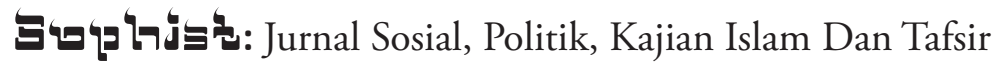

4. Pekerja anak,

5. Pelacuran anak,

6. Anak-anak diffabel,

7. Anak-anak pengungsi dan tidakberkewarganegaraan,

8. Anak-anak dalam penjara,

9. Anak-anak korban kekerasan dan terlantar. ${ }^{3}$

Keberadaan anak terlantar yang dikarenakan oleh berbagai faktor seperti dahulu dibuang oleh orang tuanya karena masalah biaya, merupakan anak yang lahir dari pasangan yang belum menikah, tidak terawat karena terdapat beberapa kendala, dan lain sebagainya. Jika hal ini dibiarkan begitu saja maka masalah ini dapat mengancam masa depan bangsa ini.

Anak-anak terlantar yang tidak mendapatkan perawatan dan perlindungan akan hak-haknya sebagaimana seharusnya tersebut akan rentan menjadi anak-anak yang memiliki disfungsi sosial atau bahkan tidak memiliki masa depan jika tidak segera ditangani dengan baik. Anak-anak tersebut harus mendapatkan penanganan yang baik sehingga dapat tumbuh berkembang seperti layaknya anak normal yang diasuh oleh orang tua mereka sendiri.

Berbagai upaya telah dilakukan oleh pemerintah untuk menjamin adanya perlindungan terhadap anak dari sasaran tindak kekerasan dan kejahatan ini, meskipun belum begitu optimal dalam prakteknya. Perlindungan tersebut berupa tindakan preventif dan represif. Dalam hal ini pemerintah sudah menyiapkan berbagai perangkat hukum untuk mengatasinya. Seperti dengan diberlakukannya UU nomor 23 Tahun 2002 Tentang Perlindungan Anak.

Perlindungan anak tersebut berkaitan erat untuk mendapatkan hak asasi mutlak dan mendasar yang tidak boleh dikurangi satupun atau mengorbankan hak mutlak lainnya untuk mendapatkan hak

3 Candra Gautama, Konvensi Hak Anak: Panduan Bagi Jurnalis, (Jakarta: LSPP, 2001), hlm. 6-10. 
lainnya, sehingga anak tersebut akan mendapatkan hak-haknya sebagai manusia seutuhnya bila ia menginjak dewasa. Dengan demikian, bila anak dewasa, maka anak tersebut akan mengetahui dan memahami mengenai segala sesuatu yang menjadi hak dan kewajiban baik terhadap keluarga, masyarakat, bangsa dan negara.

\section{B. Pembahasan}

\section{Problematika Adopsi Dalam Sosial Kemasyarakatan dan Hukum}

Anak sebagai salah satu unsur dari suatu keluarga, mengalami hubungan-hubungan antara pribadi yang pertama-tama dalam keluarga, misalnya hubungan anak dengan orang tuanya, anak dengan sesama anak yang lain, anak dengan anggota kerabat orang tuanya (ibu atau ayahnya). Menurut Soerjono Soekanto, yang mengutip pendapat Koentjaraningrat: "suatu keluarga berfungsi sebagai kelompok di mana individu itu pada dasarnya dapat menikmati bantuan dari sesamanya serta keamanan hidup dan kelompok di mana individu itu, waktu ia sebagai anak-anak dan belum berdaya, mendapat asuhan dan permulaan dari pendidikannya." ${ }^{4}$

Dapat dinyatakan bahwa ada beberapa golongan anak yang dapat disebutkan yakni: pertama; anak kandung, yaitu anak yang dilahirkan dari pasangan suami istri yang sah dan memiliki hubungan darah terhadap orang tuanya. Kedua; anak angkat, yaitu anak yang diambil oleh sesorang sebagai anaknya, dipelihara, dipenuhi segala kebutuhannya, serta diperlakukan sebagai anak sendiri dan berhak atas warisan orang yang mengangkatnya, apabila orang tua angkatnya meninggal. Ketiga; anak piaraan, yaitu anak yang dipelihara oleh seseorang supaya tumbuh menjadi dewasa dan sehat. Keempat; anak tiri, yaitu anak yang ada karena hasil pernikahan lagi salah satu orang tuanya. Misalnya A duda, dan istrinya meninggal. A memiliki anak C,

4 Soerjono Soekanto, Intisari Hukum Keluarga, (Bandung: Alumni, 1980), hlm. 53. 
D, E. A menikah lagi dengan B. C, D, E ini terhadap B adalah anak tiri. Kelima; anak di luar nikah, yaitu anak yang dilahirkan sebelum ibunya kawin dengan orang yang menghamilinya. ${ }^{5}$

Hukum positif di ilndonesia maupun hukum Islam memberikan perhatian yang sangat luar biasa terhadap keberadaan anak kecil dan anak adopsi, sehingga ada beberapa hukum tentang anak kecil tersebut, yang tujuannya adalah untuk menjamin keberlangsungan hidup, kesejahteraan, kepemilikan dan perlindungan akan hak-haknya.

Pengangkatan anak sering juga diistilahkan dengan adopsi. Dalam Kamus hukum kata adopsi yang berasal dari bahasa latin adoptio diberi arti: pengangkatan anak sebagai anak sendiri. ${ }^{6}$ Sedangkan dalam kamus bahasa bahasa arab adopsi disebut juga "tabanny" yaitu menjadikannya sebagai anak. ${ }^{7}$ Dalam kamus umum bahasa Indonesia mengartikan anak angkat adalah anak orang lain yang diambil dan disamakan dengan anaknya sendiri. ${ }^{8}$

Dalam pasal 1 angka 9 Undang-Undang Perlindungan Anak , UU No 23 Tahun 2002 memberi pengertian pengangkatan anak adalah suatu perbuatan hukum yang mengalihkan seorang anak dari lingkungan kekuasaan-kekuasaan keluarga orangtua yang sah/ walinya yang sah/orang lain yang bertanggung jawab atas perawatan, pendidikan, dan membesarkan anak tersebut ke dalam lingkungan kekuasaan kekeluargaan orangtua angkat berdasarkan putusan/ penetapan pengadilan negeri. Pengertian lain adopsi adalah suatu perbuatan hukum yang memberikan kedudukan kepada seseorang anak orang lain yang sama seperti anak sah.

Sedangkan adopsi dalam hukum islam menurut Imam al-Qarafi adalah upaya seseorang untuk mengangkat seorang anak (yang bukan

5 Amir Martosedono, Pengangkatan Anak Dan Masalahnya, (Semarang : Dahara Prize, 1990), hlm. 45.

6 Andi Hamzah, Kamus Hukum, (PT Ghalia, Bandung, 1986),hlm. 28.

7 Mahmud Yunus, Kamus Arab Indonesia, (Jakarta: Hidakarya Agung, 1989), hlm. 73.

8 Poerwadarminta, Kamus Hukum Bahasa Indonesia, (Balai Pustaka, Jakarta, 1976), hlm. 120 .

Rekonstruksi Problematika Sosial .... 
anak kandung) dengan menyediakan tempat tinggal, penyediaan makanan, pakaian, tempat tidur dan kebersihan tubuh. ${ }^{9}$ Atau pendapat dari Muhammad Syarbani yang mendefinisikan adopsi sebagai usaha mendidik atau mengasuh anak yang belum mandiri atau mampu dengan perkara-perkaranya, yaitu dengan sesuatu yang baik baginya, mencegahnya dari sesuatu yang membahayakannya walaupun dalam keadaan dewasa yang gila, seperti mempertahankan dengan memandikan badannya, pakaiannya, menghiasinya, memberi minyak padanya, dan sebagainya. ${ }^{10}$

Hukum Islam melarang praktik pengangkatan anak yang mempunyai akibat hukum seperti pengangkatan anak pada masa jahiliyah, yaitu pengangkatan anak yang mengubah status anak angkat menjadi anak kandung dan terputus hubungan anak angkat dengan orang tua kandungnya, anak angkat menjadi ahli waris, dan orang tua angkat menjadi wali mutlak terhadap anak angkat. Hukum Islam hanya mengakui pengangkatan anak dalam pengertian beralihnya tanggung jawab untuk memberikan nafkah, mendidik, memelihara, dan lain-lain dalam konteks beribadah kepada Allah SWT.

Syeikh Yusuf Qardhawi menyatakan tentang keharaman praktek adopsi yang menjadikan seseorang sebagai anak secara hukum dan dinisbatkan kepada keluarga yang mengangkatnya padahal sebenarnya dia bukanlah anak sendiri. Bahkan, dikukuhkan oleh hukum yang mengatur tentang anak, dengan menetapkan berbagai akibat hukumnya, seperti diperbolehkannya bercampur baur, haram dinikahi, juga hak-hak pewarisan. Akan tetapi, mengambil anak dalam pengertian untuk pengasuhan dan mengambil alih fungsi pendidikan dari orang tua asalnya, seperti mengambil anak yatim dan anak terlantar lalu diperlakukannya seperti anak sendiri dalam hal kasih sayang, perhatian, dan pendidikan dengan tidak menisbatkan kepada diri si pengambil anak dan tidak pula mengukuhkan hukum

9 Ahmad bin Idrîs bin Abdurrahmân ash-Shonhajî Syihâbuddîn Al-Qarâfî, Anwâr al-Burûq fî Anwâi al-Furûq (Beirut: 'Âlim al-Kutub, tt.), Juz II, hlm., 140.

10 Muhammad Syarbani, Al-Iqna', (Beirut : Dar al-Fikr, t.t), hlm. 489. 
anak tersebut sebagaimana anak sendiri diperbolehkan oleh Islam. Menurutnya, praktek seperti itu sangat dipuji oleh Islam. ${ }^{11}$

Dalam hukum islam, pengangkatan anak tidak membawa akibat hukum seperti layaknya anak kandung, termasuk dalam kaitannya dengan perwalian dan pewarisan. Hak ini dikarenakan antara orang tua angkat dan anak angkat tidak ada hubungan darah, sehingga dalam perwalian maka anak angkat tersebut masih tetap dibawah perwalian orang tua kandungnya, dan anak tersebut tetap menggunakan nama dari ayah kandungnya. Begitu juga dalam pewarisan, ia tetap menjadi ahli waris dari orang tua kandungnya. Pada prinsipnya dalam hukum kewarisan islam terjadi akibat adanya hubungan darah, anak angkat tidak dapat waris mewaris dengan orang tua angkatnya. Namun demikian anak angkat dimungkinkan untuk mendapatkan bagian dari harta peninggalan melalui washiat wajibah. Menurut pasal 209 Kompilasi Hukum Islam menyatakan bahwa seorang anak angkat berhak 1/3 (sepertiga) bagian dari harta peninggalan orang tua angkatnya sebagai suatu washiat wajibah.

Adopsi mempunyai pengertian memberlakukan anak angkat hanya sebagai rasa cinta dengan memberikan makan ataupun memberi sesuai kebutuhan yang bukan memberlakukan sebagai anak nasabnya sendiri adalah hukumnya mubah dan memperbolehkan adanya praktek adopsi.

Sedangkan dalam Kitab Undang-Undang Hukum Perdata, dalam Staatblaad 1917 No. 129 menerangkan bahwa akibat hukum dari pengangkatan anak adalah anak tersebut secara hukum memperoleh nama dari bapak angkat, dijadikan sebagai anak yang dilahirkan dari perkawinan orang tua angkat dan menjadi ahli waris orang tua angkat. Artinya akibat pengangkatan tersebut, maka terputus segala hubungan perdata, yang berpangkal pada keturunan karena kelahiran, yaitu anatara orang tua kandung dan anak tersebut. Karena status anak angkat sama dengan anak kandung dari orang tua angkatnya

11 Yusuf Al Qardhawi, Halal dan Haram dalam Islam ( alih bahasa oleh Wahid Ahmadi, Dkk), (Surakarta: Era Intermedia, 2003), hlm. 317-319. 
maka dengan demikian pembagian warisan berlaku sama dengan anak kandung seperti tercantum dalam pasal 857 KUHPerdata.

\section{Adopsi Sebuah Upaya Penanggulangan Masalah Sosial Dalam Upaya Perlindungan Anak}

Didalam kehidupan rumah tangga, ada beberapa keluarga yang tidak memiliki kesempatan untuk memiliki anak kandung. Ada banyak kemungkinan yang menyebabkan hal ini terjadi, karena faktor medis, faktor usia, atau mungkin belum diberi kesempatan untuk memiliki anak oleh Tuhannya. Rumah tangga yang belum dikaruniai anak kandung, menganggap adopsi merupakan jalan yang tepat. Beberapa keluarga yang mengadopsi anak sebagai "pancingan" agar secepat mungkin dikaruniai anak kandung. Disisi lain ada juga yang mengadopsi anak untuk meringankan beban orang tua kandung si anak, terlebih lagi jika orang tua kandung anak tersebut berasal dari keluarga yang tidak mampu.

Dalam pasal 34 ayat 1 Undang-Undang Dasar Negara Republik Indonesia tahun 1945 telah disebutkan: "Fakir miskin dan anak terlantar dipelihara oleh negara". Praktek adopsi saat ini adalah merupakan hal yang wajar dilakukan bagi setiap orang. Baik bagi mereka yang belum dikaruniai keturunan maupun yang telah dikaruniai keturunan. Karena hal ini diperbolehkan oleh UndangUndang dan telah diatur dalam ketentuan-ketentuan hukum.

Adopsi merupakan alternatif untuk menyelamatkan perkawinan atau untuk mencapai kebahagiaan rumah tangga, karena "Tujuan dari perkawinan yang dilakukan, pada dasarnya adalah untuk memperoleh keturunan, yaitu anak. Begitu pentingnya hal keturunan (anak) ini, sehingga menimbulkan berbagai peristiwa hukum, karena, misalnya, ketiadaan keturunan (anak). Perceraian, poligami dan pengangkatan anak merupakan beberapa peristiwa hukum yang terjadi karena alasan di dalam perkawinan itu tidak memperoleh keturunan (walaupun bukan satu-satunya alasan). Tingginya frekuensi perceraian, poligami 
dan pengangkatan anak yang dilakukan didalam masyarakat mungkin merupakan akibat dari perkawinan yang tidak menghasilkan keturunan, maka tujuan perkawinan itu tidak tercapai." ${ }^{12}$

Ada beberapa syarat yang harus dipenuhi ketika ingin mempunyai anak angkat sehingga akan berdampak terhadap perlindungan dan pemenuhan hak-hak anak yakni:

a. Diutamakan pengangkatan anak yatim piatu;

b. Anak yang cacat mental, fisik, sosial;

c. Orang tua anak tersebut memang sudah benar-benar tidak mampu mengelola keuangannya;

d. Bersedia memupuk dan memelihara ikatan keluarga antara anak dan orang tua kandung sepanjang hayat;

e. Hal-hal lain yang tetap mengembangkan manusia seutuhnya. ${ }^{13}$ Adopsi disebut sebagai salah satu jalan untuk menanggulangi dan mengurangi beban penderitaan perekonomian masyarakat miskin maupun masyarakat anak jalanan itu sendiri. Tidak boleh dilupakan bahwa keberadaan anak-anak merupakan asset bangsa sebagai generasi penerus pembangunan dan perjuangan bangsa indonesia.

Diperlukan adanya pemberdayaan dan pemberian kesempatan kepada anak bangsa yang terlantar di jalanan, terutama dalam aspek pendidikan yang mana mereka kurang mendapatkan semestinya di usia belajar. Melihat situasi dan kondisi diatas, hal ini merupakan tugas kewenangan dan tantangan bagi seluruh komponen Negara dan masyarakat untuk melindungi hak-hak mereka, terlebih bagi pemerintah untuk memberikan perlindungan, sandang, papan, pangan dan juga pendidikan kepada anak usia sekolah.

Pasal 3 Undang-Undang No. 23 tahun 2002 tentang Perlindungan Anak menyebutkan bahwa perlindungan anak bertujuan

12 Soerjono Soekanto dan Soleman B. Takeko, Hukum Adat Indonesia, (Jakarta; Rajawali, 1983), hlm. 275.

13 Irma Setyowati Soemitro, Aspek Hukum Perlindungan Anak, (Jakarta: Bumi Aksara, 1990), hlm. 38. 
untuk menjamin terpenuhinya hak-hak anak agar dapat hidup, tumbuh, berkembang, dan berpartisipasi secara optimal sesuai dengan harkat dan martabat kemanusiaan, serta mendapat perlindungan dari kekerasan dan diskriminasi, demi terwujudnya anak Indonesia yang berkualitas, berakhlak mulia, dan sejahtera.

Pelayanan tehadap anak terlantar dapat dilakukan dengan dua sistem, pertama: sistem panti yakni pelayanan terhadap anak terlantar dengan menempatkan anak dalam suatu panti. Pelaksanaanya selama ini sering kita kenal dengan sebutan Panti Asuhan, kedua: sistem non panti, yakni pelayanan terhadap anak terlantar dimana anak memperoleh asuhan dari keluarga/ masyarakat sebagai pengganti orang tua.

Upaya untuk mengurangi prosentase anak yang berada di jalanan untuk memenuhi kebutuhan hidup sehari-harinya, diperlukan adanya uluran tangan dan peduli terutama bagi masyarakat yang mampu, adopsi bukan merupakan hambatan bagi kalangan mampu. Dan apabila golongan masyarakat yang mampu memberikan dukungan untuk mewujudkan dan meningkatkan kualitas anak serta memberikan ataupun santunan berupa biaya pendidikkan atau sarana penampungan bagi anak jalanan sebagai wujud kepedulian terhadap anak jalanan itu sendiri, bila hal ini dapat dilakukan disetiap kota dan rasa peduli yang tinggi terhadap lingkungan masyarakat miskin, tentu anak jalanan lambat laun akan sirna dan lebih senang tinggal bersama orang tuanya atau inggal ditempat-tempat penampungan untuk belajar lebih giat lagi. Bila hal ini dapat berjalan sesuai dengan rencana dari angan-angan maka tindakan ini merupakan solusi pengadopsian anak jalanan.

Ada berbagai macam cara untuk memberikan perlindungan bagi anak terlantar antara lain :

a. Pengadaan bantuan secara total biaya pendidikan untuk anak usia sekolah SD sampai dengan SMP,

b. Pemberian rekomendasi kepada panti asuhan maupun calon 


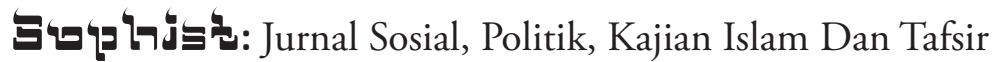

orang tua angkat bagi anak terlantar yang terjaring dalam razia mulai dari pembinaan sampai dengan pemulangan ke daerah asalnya,

c. Pemberian tambahan gizi bagi anak balita terlantar.

Setelah terjadi praktek adopsi ada beberapa aspek yang harus diperhatikan, sebagaimana tercantum dalam pasal 209 ayat (1) dan (2) Buku II Kompilasi Hukum Islam disebutkan bahwa :

(1) Harta peninggalan anak angkat dibagi berdasarkan pasal-pasal 173 sampai dengan 193 tersebut diatas. Sedangkan terhadap orang tua angkat yang tidak menerima wasiat diberi wasiat wajibah sebanyak $1 / 3$ dari harta warisan anak angkatnya.

(2) Terhadap anak angkat yang tidak menerima wasiat diberi wasiat wajibah sebanyak-banyaknya $1 / 3$ dari harta orang tua angkatnya.

Pasal ini merupakan gagasan baru dan produk ijtihad yang dilahirkan oleh ulama Indonesia, dengan menyebutkan ketentuan keberadaan anak angkat maupun orang tua angkat yang memperoleh hak harta warisan lebih didasarkan pada pertimbangan kemanusiaan, keadilan, dan adanya keinginan untuk memilih alternatif yang terbaik (padahal anak angkat maupun orang tua angkat dalam Islam sudah dihapus dari menerima hak waris).

Tujuan adopsi lebih berorientasi pada kepedulian sosial dengan membantu anak-anak yang lemah dari segi financial perekonomiannya tanpa memutus hubungan nasab antara anak angkatnya dengan orang tuanya, praktek semacam ini sangat dianjurkan dalam syari'at Islam. Sementara anak angkat diberikan hak untuk menerima bagian harta ayah angkatnya, dan begitu pula dengan ayah angkat yang menerima haknya untuk mendapatkan bagian harta waris dari anak angkatnya melalui wasiat wajibah, semata-mata didasarkan pada pandangan ulama Indonesia yang menganggap ada hak yang harus diberikan kepada anak angkat maupun orang tua angkat atas pengabdian dan 
jasanya. Oleh karena prosesnya melalui wasiat wajibah maka kadarnya pun dibatasi hanya sampai $1 / 3$ saja, sehingga dapat menutup adanya klaim pengakuan anak angkat terhadap seluruh harta ayah angkatnya dan begitu pun sebaliknya. Selain itu menurut hemat penulis, pasal ini tidak lepas dari pengaruh hukum adat yang berlaku di negara Indonesia, di mana adopsi merupakan salah satu sebab saling mewarisi. ${ }^{14}$

Berdasarkan konsep Islam, pengangkatan seorang anak tidak boleh memutus nasab antara si anak dengan orang tua kandungnya. Hal ini kelak berkaitan dengan sistem waris dan perkawinan. Dalam perkawinan misalnya, yang menjadi prioritas wali nasab bagi anak perempuan adalah ayah kandungnya sendiri. Dalam waris, anak angkat tidak termasuk ahli waris. Pengangkatan anak berdasarkan hukum Islam adalah pengangkatan anak yang bersumber pada $\mathrm{Al}$ Qur'an dan sunnah serta hasil ijtihad yang berlaku di Indonesia yang diformulasikan dalam berbagai produk pemikiran hukum Islam, baik dalam bentuk fikih, fatwa, putusan pengadilan, maupun peraturan perundang-undangan, termasuk didalamnya Kompilasi Hukum Islam

Hukum islam menggariskan bahwa hubungan hukum antara orang tua angkat dengan anak angkat terbatas sebagai hubungan antara orang tua asuh dengan anak asuh yang diperluas, dan sama sekali tidak menciptakan hubungan nasab. Akibat hukum dari pengangkatan anak dalam islam hanyalah terciptanya hubungan kasih dan sayag dan hubungan tanggung jawab sebagai sesame manusia. Karena tidak ada hubungan nasab, maka konsekuensi hukum lainnya adalah antara orang tua angkat dengan anak angkat harus menjaga mahram, dan karena tidak ada hubungan nasab, maka keduanya dapat melangsungkan perkawinan.

\section{Penutup}

Salah satu yang menjadi permasalahan di negeri ini adalah banyaknya anak usia sekolah yang tidak dapat melanjutkan sekolah 14 Fatchur Rahman, Ilmu Waris, (Bandung: PT. Al-Ma'arif, 1981), hlm. 63. 
akibat bencana dan lain lain, dikota-kota besar anak-anak terlantar dengan usia sekolah dapat dengan mudah ditemui dipinggir jalan, terminal, stasiun dan sebagainya. Anak-anak apapun latar belakangnya merupakan investasi masa depan, setiap anak pada hakikatnya mempunyai hak dan kewajiban sebagai seorang anak dalam sebuah keluarga, akan tetapi dalam kenyataannya seringkali dijumpai adanya pengabaian terhadap pemenuhan hak-hak anak, hal ini tidak tertutup kemungkinan dikarenakan kondisi ekonomi, sosial dan psikologi keluarganya.

Perlindungan anak adalah suatu usaha yang mengadakan kondisi dimana setiap anak dapat melaksanakan hak dan kewajibanya. Adapun perlindungan anak merupakan perwujudan adanya keadilan dalam suatu masyarakat. Dengan demikian maka perlindungan anak harus diusahakan dalam berbagai bidang kehidupan bernegara dan bermasyarakat. Perlindungan anak merupakan suatu bidang pembangunan nasional. Melindungi anak adalah melindungi manusia agar membangun manusia seutuhnya. Hakekat pembangunan nasional adalah upaya yang dilaksanakan oleh semua komponen bangsa dalam rangka mencapai tujuan bersama (Pasal 1 Undang-Undang No. 25 tahun 2004), mengabaikan masalah perlindungan anak tidak akan memantabkan Pembangunan Nasional. Akibat tidak adanya perlindungan anak akan menimbulkan berbagai permasalahan sosial yang dapat mengganggu ketertiban, keamanan, dan pembangunan nasional. Maka ini berarti bahwa perlindungan anak harus diusahakan apabila kita ingin mengusahakan pembangunan nasional yang memuaskan.

Perlindungan dan pemenuhan kebutuhan orang tua untuk anak dapat terwujud, apabila orang tua merasa mampu untuk mencukupi hak-hak anak, sehingga anak tidak menjadi terlantar. Tetapi pada kenyataannya, anak-anak dilahirkan tanpa adanya pemenuhan hak yang seimbang. Dengan adanya hal tersebut, orang tua akan menyerahkan anak yang dilahirkan ke panti asuhan, dengan 
Vol. 1, No. 1, Juni 2018

harapan hak-hak anak akan dapat dipenuhi. Dalam hal inilah, Negara melakukan perlindungan kepada anak-anak terlantar yang berada di panti asuhan, melalui Dinas Kesejahteraan Sosial yang ada. 


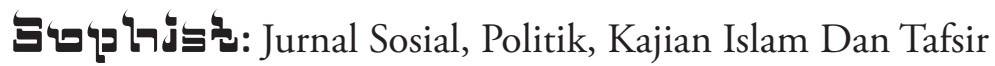

\section{Daftar Pustaka:}

Ahmad bin Idrîs bin Abdurrahmân ash-Shonhajî Syihâbuddîn AlQarâfî, Anwâr al-Burûq fì Anwâi al-Furûq (Beirut: 'Âlim alKutub, tt.)

Amir Martosedono, Pengangkatan Anak Dan Masalahnya, (Semarang: Dahara Prize, 1990)

Andi Hamzah, Kamus Hukum, (PT Ghalia, Bandung, 1986)

Candra Gautama, Konvensi Hak Anak: Panduan Bagi Jurnalis, (Jakarta: LSPP, 2001)

Irma Setyowati Soemitro, Aspek Hukum Perlindungan Anak, (Jakarta: Bumi Aksara, 1990)

Mahmud Yunus, Kamus Arab Indonesia, (Jakarta: Hidakarya Agung, 1989)

Muhammad Syarbani, Al-Iqna', (Beirut : Dar al-Fikr, t.t)

Poerwadarminta, Kamus Hukum Bahasa Indonesia, (Balai Pustaka, Jakarta, 1976)

Soerjono Soekanto dan Soleman B. Takeko, Hukum Adat Indonesia, (Jakarta; Rajawali, 1983)

Soerjono Soekanto, Intisari Hukum Keluarga, (Bandung: Alumni, 1980)

Yusuf Al Qardhawi, Halal dan Haram dalam Islam (alih bahasa oleh Wahid Ahmadi, Dkk ), (Surakarta: Era Intermedia, 2003) 